\title{
Baltic Sea coastal erosion; a case study from the Jastrzębia Góra region
}

\author{
Grzegorz Uścinowicz", Regina Kramarska, Dorota Kaulbarsz, Leszek Jurys, \\ Jerzy Frydel, Piotr Przezdziecki, Wojciech Jegliński
}
Polish Geological Institute-National Research Institute, Marine Geology Branch; Kościerska 5, 80-328 Gdańsk, Poland; e-mail: grzegorz.uscinowicz@pgi.gov.pl
${ }^{*}$ corresponding author

\begin{abstract}
The coastline in the Jastrzębia Góra area can be divided into three major zones of general importance: a beach and barrier section, a cliff section, and a section protected by a heavy hydrotechnical construction. These areas are characterised by a diverse geology and origin, and hence different vulnerability to erosion. In addition, observations have demonstrated a different pace of erosion within each zone. Based on the results obtained by remote sensing methods (analysis of aerial photographs and maps), it has been determined that the coastline in the barrier area, i.e., to the west of Jastrzębia Góra, moved landwards by about $130 \mathrm{~m}$, in a period of 100 years, and $80 \mathrm{~m}$ over about 50 years. A smaller displacement of the shoreline could be observed within the cliff. Between the middle of the twentieth and the start of the twenty-first centuries the shore retreated by about $25 \mathrm{~m}$. However, in recent years, an active landslide has led to the displacement of the uppermost part of the cliff locally up to $25 \mathrm{~m}$. Another issue is, functioning since 2000, a heavy hydrotechnical construction which has been built in order to protect the most active part of the cliff. The construction is not stable and its western part, over a distance of $50 \mathrm{~m}$, has moved almost $2 \mathrm{~m}$ vertically downwards and c. $2.5 \mathrm{~m}$ horizontally towards the sea in the past two years. This illustrates that the erosional factor does not comprise only marine abrasion, but also involves land-based processes determined by geology and hydrogeology. Changes in the shoreline at the beach and barrier part are constantly conditioned by rising sea levels, the slightly sloping profile of the sea floor and low elevation values of the backshore and dune areas. Cliffs are destroyed by mass wasting and repetitive storm surges that are responsible for the removal of the colluvium which protects the coast from adverse wave effects. Presumably, mass movements combined with groundwater outflow from the cliff, plus sea abrasion cause destabilisation of the cliff protection construction.
\end{abstract}

Keywords: barrier and cliff coast, coastal landslides, coastal erosion, coastal protection, southern Baltic Sea

\section{Introduction}

The southern Baltic coast is an active area of essential socio-economic and natural importance which is exposed to environmental changes. It is also subject to a strong human pressure. In order to meet the increased demand for information on coastal transformation, problems of shore erosion have been studied for a considerable time, using different methods (e.g., Musielak, 1991; Rotnicki et al., 1995; Subotowicz, 1982, 1995; Zeidler, 1995; Bitinas et al., 2005; Kallio, 2006; Hoffmann \& Lampe, 2007; Valdmann et al., 2008; Zhang et al., 2010; Zhang et al., 2011; Bagdanavičiute et al., 2012; Zawadzka, 1999, 2012; Jarmalavičius et al., 2013; Kolander et al., 2013). Most often, authors have linked coastal erosion to an increased frequency of heavy storms and accelerated sea level rise. A key issue in the relationship between the rate of erosion and the geological structure of the coastal zone has 
been mentioned less often, in regard to cliff and barrier coasts alike.

The Polish Baltic open sea coast is $498 \mathrm{~km}$ long. Pleistocene and Holocene deposits occur along the entire Polish coastal zone, both inland and offshore. Only locally, on the western coast of the Gulf of Gdańsk, do Miocene deposits crop out in cliffs. Barrier-type coasts, with a length of $380 \mathrm{~km}$, predominate. Cliff length measures c. $101 \mathrm{~km}$, while low coasts, similar to wetlands, comprise $c .17 \mathrm{~km}$ (Uścinowicz et al., 2004). Two basic barrier types that differ in morphology and processes governing their evolution occur on the Polish coast. The first type includes stationary (accreted) barriers with well-developed high dune systems, while the second comprises narrow and low landward-migrating barriers (Uścinowicz, 2003). Three basic cliff types are distinguished on the basis of their geological structure and related types of mass movements: cliffs dominated by tills and eboulements, cliffs dominated by sands and landslips and cliffs with complex structures and dominated by landslides (Subotowicz, 1982, 1995a, b; Uścinowicz et al., 2004; Ilcewicz-Stefaniuk et al., 2005; Carpenter et al., 2013).

All types of coast are affected by changing sea level and storms. A widely held view is that storm frequency and rate of sea level rise have increased during the last decades (e.g., Dziadziuszko \& Wróblewski, 1990; Dziadziuszko \& Malicki, 1993; Suursaar et al., 2006; Wiśniewski \& Wolski, 2009; Navrotskaya \& Chubarenko, 2012; Weisse et al., 2014). However, there also are data on a decrease of storm frequency during the years 1971-2009 (Formela \& Marsz, 2011). HELCOM reports $(2007,2013)$ indicate that the occurrence of storms in the Baltic Sea is overprinted by large-scale multidecadal variations rather than long-term trends. In general, sea level along the southern coast of the Baltic Sea has been rising. Differences in the rate of sea level rise are due to fluctuations in land subsidence and meteorological factors, such as wind forcing and air pressure (Uścinowicz, 2006). At a decadal time scale, Baltic Sea level variations are closely associated with the North Atlantic Oscillation (HELCOM 2007, 2013). Based on mareographic records from Gdańsk, sea level rose at a rate of $4.6 \mathrm{~mm}$ per annum in the period 1886-1906 and $5.7 \mathrm{~mm}$ per annum in the period 1970-1990, whereas in the first half of the twentieth century and near the turn of the twentieth and twenty-first centuries, the rate of sea level rise slowed down (Jurys \& Uścinowicz, 2014).

The western part of the cliff coast in the Jastrzębia Góra region (Fig. 1) has been a training ground for studies of slope stability for many years (Kramarska et al., 2011; Subotowicz, 1982, 1989, 1991, 1995a, b, 2000). Historical data and results of longterm measurements indicate high cliff activity. Although the process of erosion and shoreline retreat is variable over time, it is especially intense during frequent strong storm surges (Subotowicz, 1989, 1995a, b).

The beach and barrier part of the coast in the west is also exposed to substantial erosion; this has increased during the latter part of the twentieth century. Intense erosion of the barrier part may result

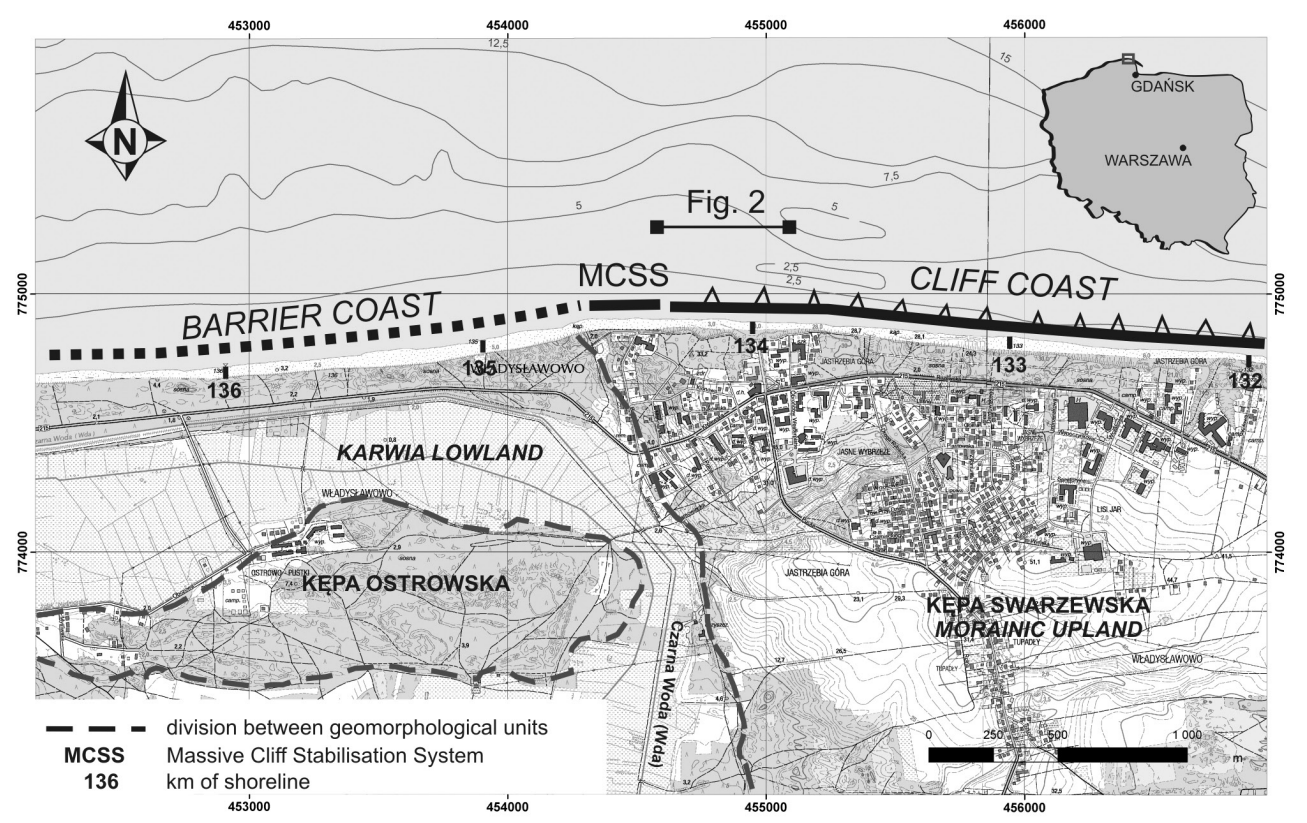

Fig. 1. Map of the study area 
in the risk of flooding of low-lying areas situated more landward (Zawadzka, 2005).

Protective measures along the coast have been conducted since the nineteenth century. However, in the study area the first seawall at the foot of the cliff was built only in 1994. The most characteristic feature is the construction (massive cliff stabilization system, MCSS) which was put in place in 2000, so as to protect the most active part of the cliff. Its existence has an impact on this sensitive section of the Polish coast.

The aim of the present study was to collect, measure and process data in order to identify changes in the morphology of the coastal zone in the context of geological and hydrogeological conditions. A major goal was the recognition of accumulation and erosion patterns in relation to morphology and geological structure of both offshore and inshore.

\section{Study area}

The study area is located in the northernmost part of Poland, along the Kaszuby Coast, and extends along a $4-\mathrm{km}$ stretch of coastline, covering areas $2 \mathrm{~km}$ offshore and $2 \mathrm{~km}$ inland. Morphologically, the area encompasses two different segments, i.e., the western part of the moraine-bearing upland of Kępa Swarzewska and the eastern part of the Karwia Lowland (Fig. 1). The barrier is developed on the lowland and the cliff coast on the upland part of the area. Jastrzębia Góra, a popular holiday resort, is situated in the eastern part of the area.

The geological setting of this area closely matches this morphological division. The Karwia Lowland consists of fluvioglacial sands covered by Holocene lacustrine sediments and peat. The barrier coast of the Karwia Lowland is narrow and low, and consists of marine sands overlain by dunes (aeolian cover). Dunes are not higher than $5 \mathrm{~m}$ and, in general, the thickness of the marine sands does not exceed $3 \mathrm{~m}$. Locally, peat is exposed on the beach after storms. The footslopes of the dunes are protect- ed by a seawall. Sands of the migrating barrier enter the peaty depression of Czarna Woda (Wda). In the southern part, Czarna Woda runs northwards and represents the border between the moraine-bearing upland and lowland areas. The river changes its course in the vicinity of Jastrzębia Góra, running close to parallel to the shoreline, and after approximately $3.5 \mathrm{~km}$, it flows into the sea. To the south and west of a peaty depression of Czarna Woda (Wda) lies a small elevation of Pleistocene deposits (Kępa Ostrowska). It consists of fine-grained fluvial and lacustrine sands, covered by aeolian sands.

The oldest deposits in the upland of Kępa Swarzewska are of Miocene age. The top of the Miocene strata lies at a depth between17 to $c .37 \mathrm{~m}$ below sea level (Kramarska, 1999; Skompski, 1997, 2001). These are mainly silts, in some places with lignite, and fine- to medium-grained sands. The Miocene sediments are overlain by Saalian and Weichselian tills. There are three levels of till interbedded by sandy deposits and clays, cropping out in the cliff on the northwestern part of the upland (Zaleszkiewicz et al., 2000; Masłowska et al., 2002). The cliff, with a maximum height of $32 \mathrm{~m}$ a.s.l., extends over a distance of about $3 \mathrm{~km}$. A large part of the cliff face is overgrown with plants, and/or covered with landslides (Fig. 2) which precludes a detailed geological description. However, in the course of systematic, long-term studies, it has been possible to illustrated the outcrops which are periodically exposed by marine erosion. The grey till in the lowermost part of the section is dated as Saalian. In the central part of the cliff there is a consistent level of till with a maximum thickness of $20 \mathrm{~m}$. Based on results of petrographic and TL studies this has been assigned to the Middle Stadial of Weichsel Glaciation. The uppermost, youngest level of till is 5-6 m thick. It is very sandy with small quantities of gravel. Marginal lake-like deposits occur locally. Silts and clays are exposed in the cliff of Jastrzębia Góra at heights ranging between $2 \mathrm{~m}$ below to $15 \mathrm{~m}$ above sea level.

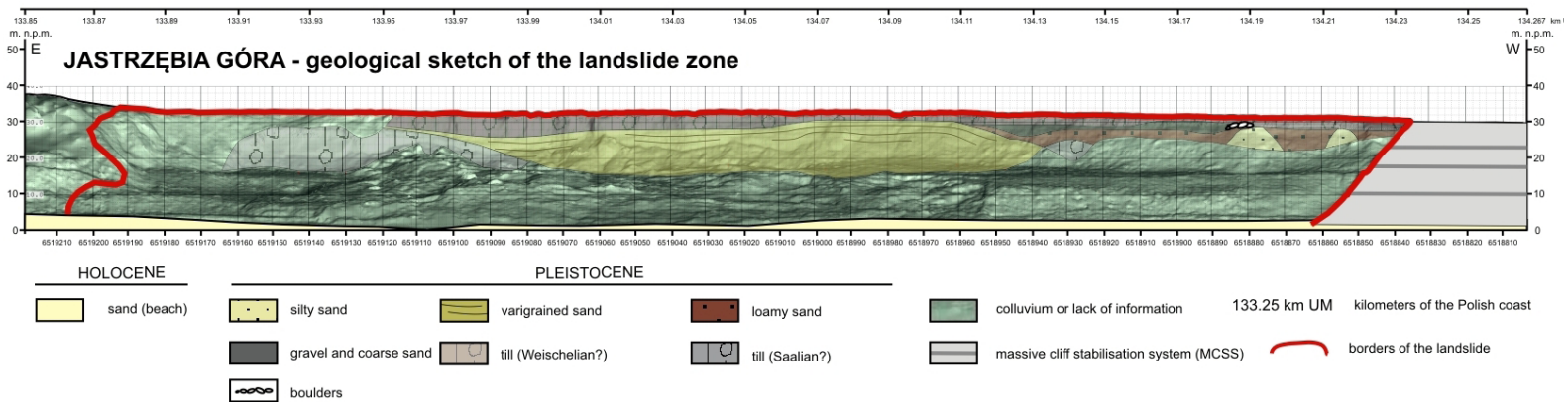

Fig. 2. Geological sketch and digital terrain model of the landslide in frontal view 
Locally, in the western part of the Kępa Swarzewska, tills are also covered by aeolian sands. The surface of the moraine plateau is locally cut by erosional valleys filled with alluvial sands and silts.

Part of the western cliff section is being protected by a massive cliff stabilisation system (MCSS). This heavy hydrotechnical construction is $235 \mathrm{~m}$ long and nearly $30 \mathrm{~m}$ in height. The construction consists of four levels/steps secured on the outer side by blocks of natural rock covered by a steel mesh (Werno, 2002; Frankowski et al., 2009). A drainage system has been set up under this protective structure. The system extends downwards from the top of the cliff to its foot.

The sea floor in the study area gradually decreases towards the north to a depth of about $17 \mathrm{~m}$. Isobaths of $2.5 \mathrm{~m}, 5 \mathrm{~m}$ and $10 \mathrm{~m}$ are more or less parallel to the shore. There are two, occasionally three bars close to the shore. They are rather low, between 0,5 and 2,5 m (Łęczyński, 2002; Zachowicz et al., 2007). Generally, the sea floor consists of Miocene strata, and locally glacitectonically deformed Oligocene(?) clays as well as Pleistocene tills and sands. The top of the Neogene and Paleogene, according to seismo-acoustic profiling and cores, is located between 18 and $12 \mathrm{~m}$ b.s.l. (Fig. 3). The sea floor has a thin (most often $<2 \mathrm{~m}$ ), discontinuous layer of marine sands (Fig. 3).
Hydrogeological conditions are complex, linked to a range of geological settings and proximity to base drainage. Kępa Swarzewska is the supply area for aquifers and also a place of groundwater outflow towards the drainage zones. Groundwater flow in the region of the plateau occurs in two directions: towards the north to the Baltic Sea (which affects cliff stability), and westwards to the valley of the River Czarna Woda (Wda).

\section{Material and methods}

The first phase of investigations has been developed around archive materials such as a historical topographic map (1908), as well as aerial photographs $(1957,2010)$. The photographs, covering all coast sections studied, were transformed into orthophotomaps. The shorelines of the topographic map and orthophotomaps were digitised and uniformed into the same scale and coordinate system, after which changes were analysed. A critical review of these materials allowed to define the main trends of accumulation/erosion processes.

The second phase included repetitive terrestrial laser scanning (TLS). The most active part of the cliff and the MCSS were scanned four times and some stretches five times. Measurements were conducted using a Riegl VZ-400 laser scanner. The

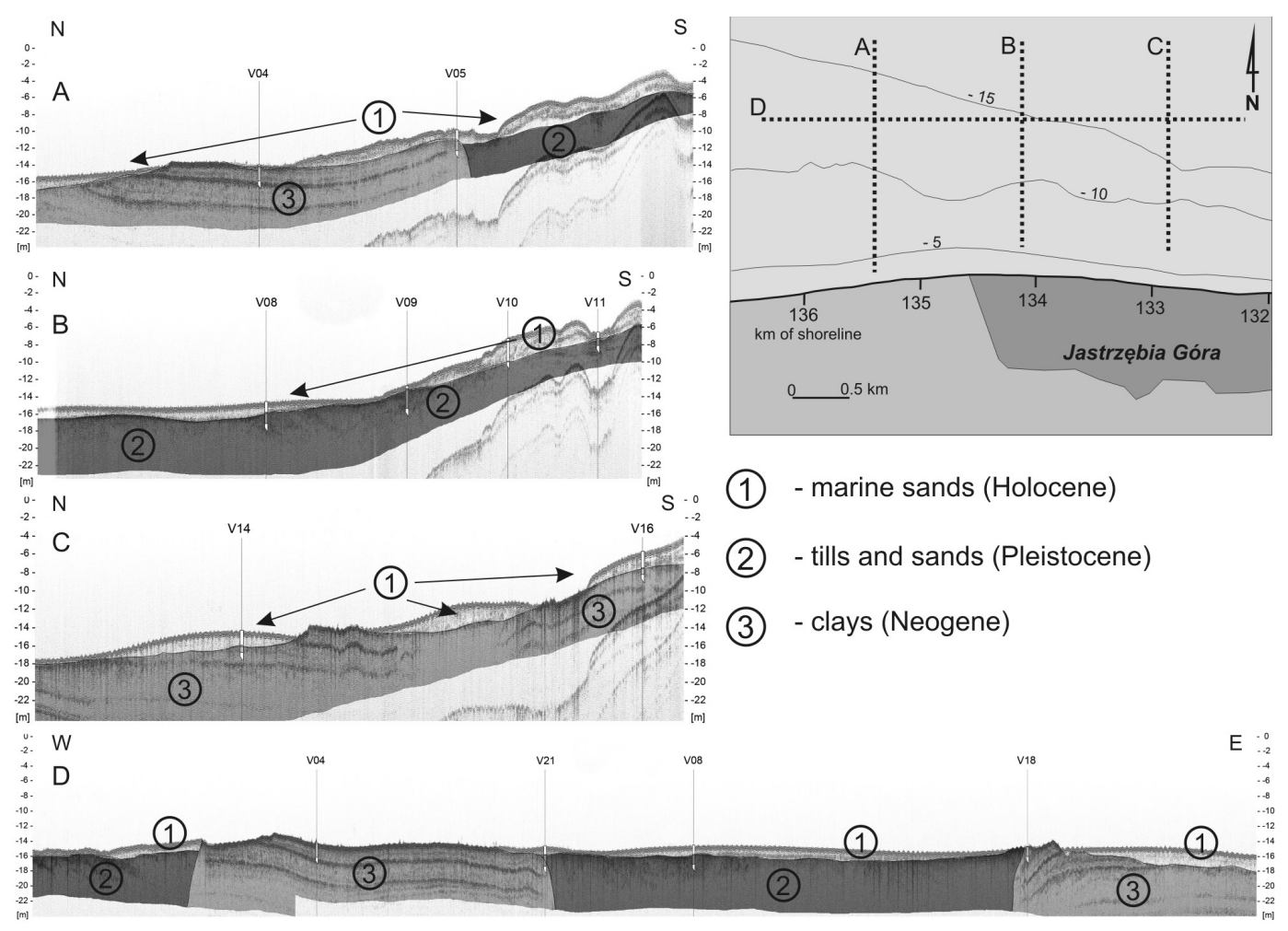

Fig. 3. Selected seismic profiles. Steep contacts between Neogene and Pleistocene result from glaciotectonic deformations 
scanner is equipped with a control panel and an integrated memory (instead a USB flash drive may be attached), responsible for proper scan pattern determination and recording data, respectively. The set also includes a calibrated Nikon D700 camera used for automatic registration of high-resolution images acquisition. The absolute orientation of the device is provided by a Trimble R8GNSS receiver along with a Trimble TSC2 controller. Measurements using the Real Time Kinematic technique are based on the ASG-EUPOS reference station system.

Additionally, surface sediments of the inland part of the study area were mapped (down to a depth of three metres). Moreover, the percussion drilling system and rotary drilling rig using Geoprobe540MT up to $12 \mathrm{~m}$ below surface have been applied.

Single and multibeam echosounding, side-scansonar and seismo-acoustic profiling have been employed to characterise the offshore area. The dense grid of bathymetric and sonar profiles ensured a full coverage of the sea floor surface and permitted the construction of a bathymetric map and sonar mosaic with a resolution higher than $2 \mathrm{~m}$. Seismo-acoustic profiling allowed the identification of geological structures down to a depth of 10-20 m below the sea floor. The geophysical data have been verified by surface sediment samples and cores of a minimum length of $2 \mathrm{~m}$.

During the last phase, the recently obtained data have been analysed and compared with past data (e.g., geological structure, contemporary observations and coastal typology).

\section{Results and discussion}

The study area at Jastrzębia Góra is strictly limited to a length of $4 \mathrm{~km}$ along the coast. The results obtained from such a small area may not be suitable for comparisons on a regional scale and, ultimately, may be largely general in nature. Shoreline retreat on the section discussed is a part of a general trend noted in changes along the Polish coast (Rotnicki, 1995; Furmańczyk, 2005; Zawadzka, 1999, 2012; HELCOM, 2007). Thus, retreat of the barrier part (one of the least-developed on the Polish coast), is predictable, but it is difficult to be precise due to the large scale of coastal protection works, i.e., the seawall construction and beach nourishment during recent years. Due to its specificity, recent changes in the beach and barrier part of the coast, are less clear than the cliff part. Protective works disrupt the natural rhythm of changes on the cliff-like coast, also on account of extensive raised seawalls in 1994 and
MCSS in 2000, plus beach nourishment. It also precludes reliable references to earlier data on the rate of erosion.

Analysis of the maps and air photographs allows to recognise general trends of coastal changes on a time scale of decades, whereas TLS permits identification of small changes in space and time frame, irrespective of coastal protective works.

The current results indicate that maximum shoreline displacement towards the land in the barrier part of the area was in the order of c. 90-95 $\mathrm{m}$ in the period 1908-1957 and c. 85-90 $\mathrm{m}$ in the period 1957-2010. The shoreline moved at an average rate of 1.8-1.9 m per annum and 1.7-1.8 m/per annum, respectively. The maximum rate in shoreline position during 100 years attained c. $150 \mathrm{~m}$, this being one of the largest changes along the Polish barrier-type coast (Zawadzka, 1999, 2012).

According to Zawadzka (2012), average sea bed inclination between the shore and the $10 \mathrm{~m}$ isobath is 1:70, whereas underwater coastal slope in other, more stable sections of the Polish barrier coast ranges between 1:120 and 1:150. The relatively steep inclination of the sea bed, together with relatively solid (cohesive) deposits underlying the marine sand and the resultant sand deficit in the offshore area, underlie large coastal erosion. The limited amount of sand results in narrow beaches and low dunes and, in effect, rapid coastal retreat. The barrier within this area is slightly developed. Its height reaches approximately $5 \mathrm{~m}$, while its width attains about $250 \mathrm{~m}$. In this case, barrier development has been also closely linked to the mouth of the River Czarna Woda (Wda), in enforcing the outflow of the river to the west, which had a negative impact on dune growth in the central part of the barrier (Zawadz$\mathrm{ka}, 2005)$. Therefore, the belt of coastal dunes in this part is narrow, which explains why this section has so far been heavily abraded. Coastal erosion is in-

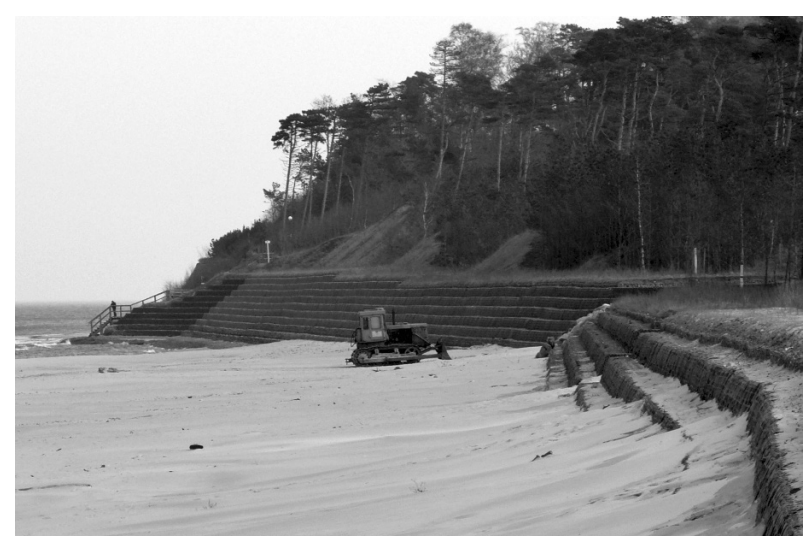

Fig. 4. Coastal protection works - seawall construction and beach nourishment 


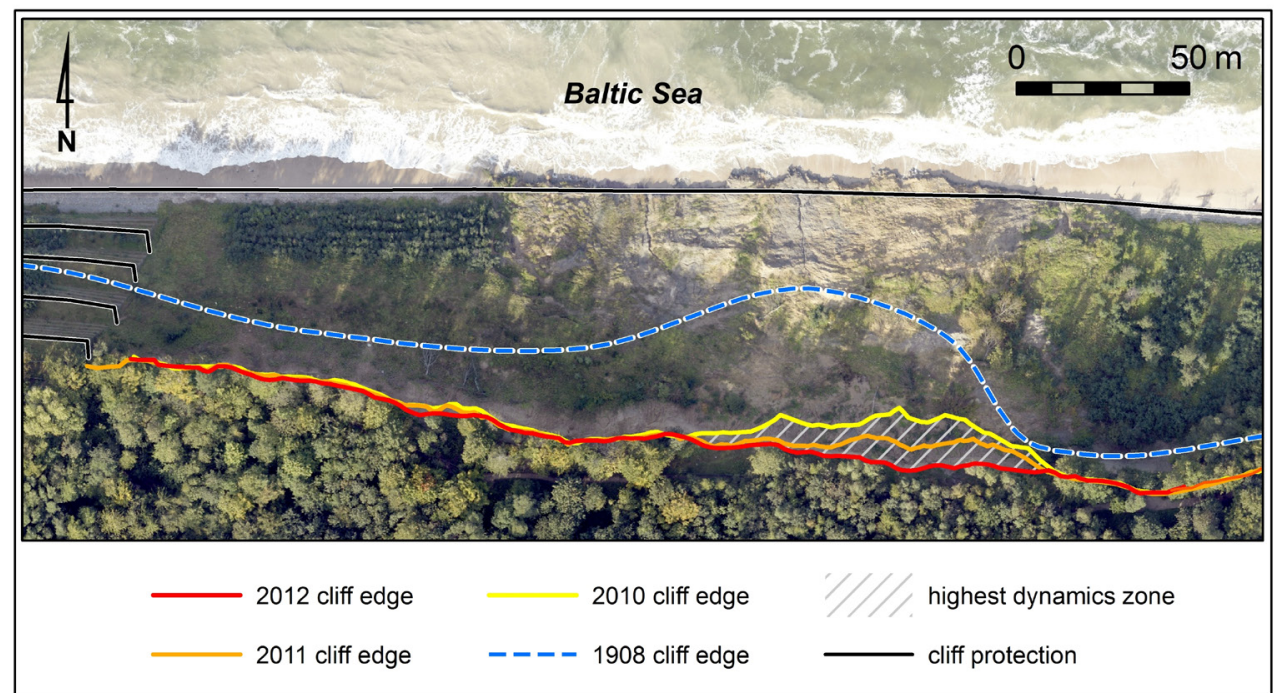

Fig. 5. Stages in cliff margin migration on the background of an aerial photograph of the landslide

tense mainly on account of autumn-winter storm surges and is observed along the entire length of the Polish coast (Furmańczyk et al., 2011; Łabuz \& Kowalewska-Kalkowska, 2011; Łabuz, 2014); however, at varying scales.

Recently, the western beach and barrier coast has been protected by seawalls (Fig. 4) over almost their entire length. This protection will put a halt to dune destruction, but not to the erosion of beach and sea floor in the nearshore, shallow areas. Beach erosion could be stopped by artificial beach nourishment and reconstruction and enlargement of the offshore sand bar system. However, it is not expected to stop the process of erosion completely, unless beach nourishment will be repeated periodically.
Analyses of maps and aerial photographs indicate a different course of coastal erosion on cliff coastal sections. The shoreline was almost stable in the period 1908-1957. Changes were close to 0 and are in the range of error in analytical methods. Shoreline stability in front of the cliff in this period was most probably due to erosion of the colluviums and supply of a large amount of sedimentary material to the coastal zone. Based on historical data, increased storm activity occurred on the Baltic at the turn of the nineteenth and twentieth centuries and large landslide took place on the Jastrzębia Góra cliff at that time (Subotowicz, 1982, 1995). Based on analyses of aerial photographs the shoreline in the period 1957-2010 shifted by about 10-35 m. In this

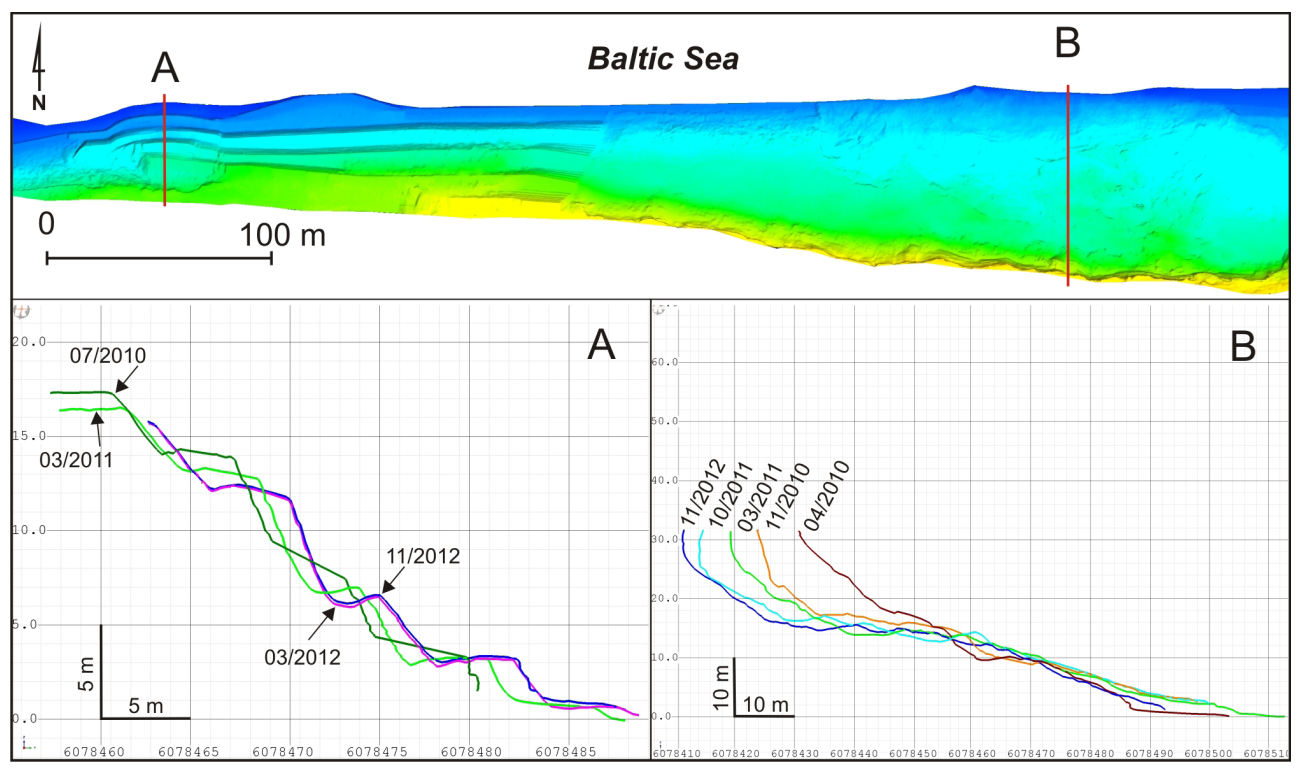

Fig. 6. Changes over time in sections of the Massive Cliff Stabilisation System (A) and the landslide (B). The upper panel shows a digital terrain model of MCSS and the landslide (orthogonal view) 
period, the shoreline moved with an average rate of 0.2-0.7 $\mathrm{m}$ per annum. However, according to other historical data, the shoreline in this section of the coast was more or less stable, perhaps even after 1957. The tower with a tourist lift was built at the footslope of the cliff in 1938-1939; it was stable and in use to 1971, when it was closed due to instability. The tower finally collapsed in January 1982.

According to Subotowicz (1982) the rate of erosion of colluviums at the footslope of the cliff (not shoreline shifting) ranged between 0.35 and $0.47 \mathrm{~m}$ per annum.

The models of cliff development proposed by Subotowicz (1989, 1995a, b) are extremely interesting in the context of the multi-annual changes observed. Unfortunately, or perhaps luckily, the predicted change of $100 \mathrm{~m} / 100$ years does not fully correspond to the newest results. This can be ascribed to a number of assumptions made by Subotowicz: marine abrasion as a dominant factor, establishing a linear regression model of the cliff and the disastrous course of changes. Displacements of the cliff edge may reach up to several metres per tens of years, but they are local (i.e., not occurring along the entire length of the cliff) and are variable in time. There are some areas prone to increased erosion and these zones have been subject to close observation and protection. These changes are mainly linked to the geological conditions and occur continuously, interspersed with periods of intensification.

A much more accurate method for monitoring changes is terrestrial laser scanning (TLS). Implementation of this method has revealed that cliff retreat dynamics vary over different parts of the cliff. In the eastern part, where the cliff is protected by a low gabion-band and the cliff top is more aligned, changes are slighter, whereas in the western part (i.e., margin of the moraine-bearing plateau) major changes due to landslides occur (Fig. 5). This process is complex and factors responsible for trig- gering a landslide might not initiate sliding until a cut-off value is reached, so that extensive slumping occurs rapidly.

The coast section protected by MCSS reveals its uneven subsidence. Its eastern and central parts remain stable, while spatial analyses of the western part show continuous displacement of MCSS and the gabion-band below. Between July 2010 and November 2012, this band advanced by as much as 2.5 metres and stages in construction work above by up to 2 metres towards the sea (Fig. 6A). Based on different views of the section, a maximum descent of the first stage by $1,3 \mathrm{~m}$, a second stage by up to $2 \mathrm{~m}$, and a third stage by up to $1,9 \mathrm{~m}$ have been detected. Locally, the gabion-band shows a tendency for slight upward movement, not exceeding 0,1 m. This situation illustrates well that the reason behind slope instability is not only marine erosion, but also land-based slumping determined by geology and hydrogeology. Even though the MCSS shows some significant deformations, changes within the adjacent, unprotected area (except for gabion-band protection) are much greater. For example, a rapid landslide activity between April 2010 and March 2011 within the cliff, resulted in the withdrawal of the top margin of the cliff locally by up to 10 metres over an 8-month period from July 2010 to March 2011 (Kramarska et al., 2011). So far, the maximum recorded cliff-top recession, between April 2010 and November 2012 (2.5 years), reached locally over 25 metres (Fig. 6B). Analyses of TLS data show a progress in landslide development of the adjacent area located eastwards of the MCSS. Landslide expansion is evident, even in cases where the main scarp retreat has not been detected, yet the sedimentary cover of a landslide colluvium (reclaimed in 2007) shows substantial deformations.

Landslide (Fig. 7) location in the marginal parts of the plateau (glaciotectonic deformation zone) is one of the reasons for its significant activity. Another reason is undoubtedly the geological structure.

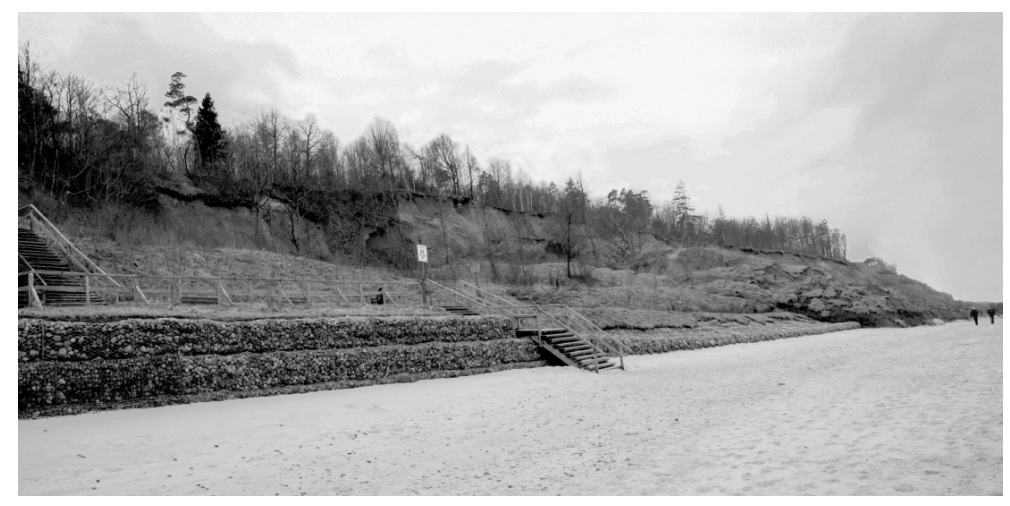

Fig. 7. A view of the landslide in 2011 
Unfortunately, this is difficult to assess. While the upper part of the landslide (i.e., main scarp) consists of massive tills and sands of different grain size, whereas the lower part of the section is impossible to trace because of its colluvium. It is likely that the lower part of the section comprises rock of a marked changeability (Kamiński et al., 2012; Subotowicz, 1991, 2000). Additionally, the situation is complicated by the irregular flow of groundwater, which contributes to the activation of mass movements. Inflow of groundwater beneath the sea floor affects the stability of the slope (cliff), when the outflow is just a short distance from the shore and takes place within non-cohesive rocks undergoing relaxation (which in turn affects the stability). Such a situation, due to the presence of cohesive Quaternary tills and Neogene clays, is of negligible importance in this case. Much more important is the groundwater flow which occurs locally in discontinuous layers, where the inflow takes place to the wall of the cliff. Monitoring of such waters is very difficult, but their presence is indicated by outflows in the cliff face. This leads to plastic deformation of the colluvium which, in combination with marine erosion, destabilises slopes. In summary, the cliff is being broken down by landslides and seasonal storm surges with wave undercutting responsible for erosion of the colluvium that protects the foot of the slope.

The problem of coastal erosion cannot be considered without taking into account the geological structure of the sea floor. Geophysical studies in the vicinity of Jastrzębia Góra have shown that the sea floor consists of consolidated Neogene clays and Pleistocene tills, with a thin cover of recent marine sands; these are missing in some places. Therefore, sediments which could serve for both protection against erosion and nourishment for the beach recovery are not available in the foreshore zone.

\section{Conclusions}

New investigations and evaluation of available data allow the following statements and conclusions to be put forward:

1. Dynamics and rates of cliff retreat vary over different parts of the cliff.

2. In the case of Jastrzębia Góra, erosion is caused not only by wave undercutting, but also landbased slumping determined by the geology and hydrogeology.

3. The greatest cliff retreat occurs within a vast landslide within the area located eastwards of the Massive Cliff Stabilisation System. The instability occurs in the area of glaciotectonic deformations as well as in places of outflow of groundwater and marine erosion. Thus, such cliffs of sophisticated natural conditions are highly vulnerable to landslide processes.

4. The part which is protected within the Massive Cliff Stabilisation System has been subject to deformation over a distance of $50 \mathrm{~m}$; it subsided locally by $2 \mathrm{~m}$ and advanced seawards by $2.5 \mathrm{~m}$ over a period of 28 months.

5. Heavy erosion occurs also on the beach and barrier coast located to the west of Jastrzębia Góra. The shoreline shifted landwards approximately $130 \mathrm{~m}$ over 100 years and $80 \mathrm{~m}$ in the period of about 50 years.

6. The sea floor is composed of Neogene clays and Pleistocene tills covered by only a thin layer of recent marine sands. Sediments which could serve for both protection against erosion and nourishment for beach recovery are not available in the foreshore zone.

7. Sea level rise is not the only factor to affect coastal erosion. Different types of coastline (barriers, cliffs) have different susceptibility; indeed, even within a single type (e.g., cliff at Jastrzębia Góra) the rate of erosion is different and changeable over time. This situation illustrates well that coastal erosion is caused not only by marine factors, but also by landward processes conditioned by geological setting and hydrogeology.

\section{Acknowledgements}

The present studies have been performed by virtue of tasks of the Polish Geological Survey, funded by a grant from the National Fund of Environmental Protection and Water Management and funds allocated for statutory activity of Polish Geological Institute - National Research Institute (no. 61.2706.1001.00). Moreover, the authors wish to thank all those who helped in the preparation of this paper.

\section{References}

Bagdanavičiute, I., Kelpšaite, L. \& Daunys, D., 2012. Assessment of shoreline changes along the Lithuanian Baltic Sea coast during the period 1947-2010. Baltica 25, 171-184.

Bitinas, A., Žaromskis, R., Gulbinskas, S., Damušyte, A., Žilinskas, G. \& Jarmalavičius, D., 2005. The results of integrated investigations of the Lithuanian coast of 
the Baltic Sea: Geology, geomorphology, dynamics and human impact. Geological Quarterly 49, 355-362.

Carpenter, N.E., Dickson, M.E., Walkden, M.J.A., Nicholls, R.J. \& Powrie, W., 2013. Effects of varied lithology on soft-cliff recession rates. Marine Geology 354, 40-52.

Dziadziuszko, Z. \& Wróblewski, A., 1990. Stany wody [State of the sea]. [In:] Majewski A. (Eds): Zatoka Gdańska [Gulf of Gdańsk]. Wydawnictwa Geologiczne. Warszawa; 120-140.

Dziadziuszko, Z. \& Malicki, J., 1993. Wzrost zagrożenia powodziami sztormowymi polskiego wybrzeża Bałtyku. Przyczyny i przebieg spiętrzeń sztormowych w styczniu i lutym 1993. [The increase of risk of storm flooding on the Polish Baltic coast. The causes of the storm surges in January and February 1993]. Gazeta Obserwatora, IMGW, 4-5, 7-12.

Formela, K. \& Marsz, A. A., 2011. Zmienność liczby dni ze sztormem nad Bałtykiem (1971-2009) [The variability of the number of a stormy days on the Baltic Sea (1971-2009)]. Prace i Studia Geograficzne 47, 189-196.

Frankowski, Z., Graniczny, M., Juszkiewicz-Bednarczyk, B., Kramarska, R., Pruszak, R., Przezdziecki, P., Szmytkiewicz, M., Werno, M. \& Zachowicz, J., 2009. Zasady dokumentowania geologiczno-inżynierskich warunków posadowienia obiektów budownictwa morskiego i zabezpieczeń brzegu morskiego [Principles of documentation of geo-engineering conditions for fundation of protective facilities on sea and seashore]. Polish Geological Institute - National Research Institute, Warszawa, 198 pp.

Furmańczyk, K., (Ed.) 2005. Zintegrowane Zarządzanie Obszarami Przybrzeżnymi - stan obecny i perspektywy. Problemy erozji brzegu [Integrated Coastal Zone Management - present state and perspectives. Problems of shore erosion]. Oficyna In Plus, Szczecin, 223 pp.

Furmańczyk, K.K., Dudzińska-Nowak, J., Furmańczyk, K.A., Paplińska-Swerpel, B. \& Brzezowska, N. 2011. Dune erosion as a result of the significant storms at the western Polish coast (Dziwnow Spit example). Journal of Coastal Research 64, 756-759.

HELCOM, 2007. Climate Change in the Baltic Sea Area - HELCOM thematic assessment in 2007, Baltic Sea Environment Proceedings 111, 49 pp.

HELCOM 2013. Climate Change in the Baltic Sea Area HELCOM thematic assessment in 2013, Baltic Sea Environment Proceedings 137, $66 \mathrm{pp}$.

Hoffmann, G. \& Lampe, R. 2007. Sediment budget calculation to estimate Holocene coastal changes on the southwest Baltic Sea (Germany). Marine Geology 243, 143-156.

Ilcewicz-Stefaniuk, D., Czerwiński, T., Koryczan, A., Targosz, P. \& Stefaniuk M., 2005. Landslides survey in the northeastern Poland. Polish Geological Institute Special Papers 20, 67-73.

Jarmalavičius, D., Žilinskas, G. \& Pupienis, D., 2013. Observation on the interplay of sea level rise and the coastal dynamics of the Curonian Spit, Lithuania. Geologija 55, 50-61.

Jurys, L. \& Uścinowicz, Sz. 2014. Naturalne i antropogeniczne czynniki kształtujace procesy geologiczne w pa- sie polskiego brzegu klifowego [Natural and anthropogenic factors determinig the geological processes on the Polish cliff coast]. [In:] Sokołowski R. (Eds): Ewolucja środowisk sedymentacyjnych regionu Pobrzeża Kaszubskiego [The evolution of sedimentary environments of Kaszuby Coast region]. Wydział Oceanografii i Geografii Uniwersytetu Gdańskiego, Gdynia, 27-37.

Kallio, H. 2006. The evolution of the Baltic Sea - Changing shorelines and unique coasts. Special Paper of the Geological Survey of Finland 41, 17-21.

Kamiński, M., Krawczyk, M. \& Zientara, P., 2012. Rozpoznanie budowy geologicznej klifu w Jastrzębiej Górze metodą tomografii elektrooporowej pod kątem zagrożenia osuwiskowego [Recognition of geological structure of the Jastrzębia Góra cliff using resistivity tomography methods for landslide hazard]. Biuletyn PIG-PIB 452, 119-130.

Kolander, R., Morche, D. \& Bimbose, M., 2013. Quantification of moraine cliff erosion on Wolin Island (Baltic Sea, northwest Poland). Baltica 26, 37-44.

Kramarska, R., 1999.Trzeciorzęd strefy brzegowej Bałtyku na odcinku Władysławowo -Jastrzębia Góra [Tertiary of the coastal zoneof the Baltic Seabetween Władysławowo and Jastrzębia Góra]. Posiedzenia Naukowe Państwowego Instytutu Geologicznego 55, 165-166.

Kramarska, R., Frydel, J. \& Jegliński, W., 2011. Zastosowanie metody naziemnego skaningu laserowego do oceny geodynamiki wybrzeża na przykładzie klifu Jastrzębiej Góry [Terrestrial laser Scanning application for costal geodynamice assesment: the case of Jastrzębia Góra cliff]. Biuletyn PIG-PIB 446, 101-108.

Łabuz, T.A. \& Kowalewska-Kalkowska, H. 2011. Coastal erosion caused by the heavy storm surge of November 2004 in the southern Baltic sea. Climate Research 48, 93-101.

Łabuz, T.A. 2014. Erosion and its rate on an accumulative Polish dune coast: The effects of the January 2012 storm surge. Oceanologia 56, 307-326.

Łęczyński, L., 2002. Morfolitodynamika podbrzeża brzegu klifowego w Jastrzębiej Górze [Morphological and lithological processes of the sea bottom in the vicinity of the Jastrzębia Góra cliff]. [In:] J. Zachowicz \& R. Kramarska, (Eds): Geologia regionu Gdańskiego - Przewodnik LXXIII Zjazdu PTG. [Geology of the Gdańsk region]. Polish Geological Institute, Gdańsk, 63-66.

Masłowska, M., Zaleszkiewicz, L., Olszak, I., Jurys, L. \& Michałowska, M., 2002. Budowa geologiczna klifu w Jastrzębiej Górze [Geological structure of Jastrzębia Góra cliff]. [In:] J. Zachowicz \& R. Kramarska (Eds): Geologia regionu Gdańskiego - Przewodnik LXXIII Zjazdu PTG. [Geology of the Gdańsk region]. Polish Geological Institute, Gdańsk, 59-62.

Musielak, S. (Eds.), 1991. Fotointerpretacyjny atlas dynamiki strefy brzegu morskiego [Remote sensing atlas of the $d y$ namics of the coast zone]. Instytut Nauk o Morzu Uniwersytetu Szczecińskiego, Szczecin.

Navrotskaya, S. E. \& Chubarenko, B. V., 2012. On the Sea Level Rise in the Russian Part of the Vistula Lagoon. Russian Meteorology and Hydrology 37, 39-46.

Rotnicki, K., Borówka, R., K. \& Devine, N., 1995. Accelerated sea level rise as a threat to the Polish coastal 
zone quantification of risk. Journal of Coastal Research 22, 111-134.

Skompski, S., 1997. Szczegótowa mapa geologiczna Polski w skali 1:50 000, ark. Puck (6) [Detailed geological map of Poland 1:50 000, sheet Puck]. Wydawnictwa Geologiczne, Warszawa.

Skompski, S., 2001. Objaśnienia do Szczegótowej Mapy Geologicznej Polski, 1:50 000, arkusz Puck (6), Puck N (1071) [Explanatory notes for Detailed geological map of Poland 1:50 000, sheet Puck] Wydawnictwa Geologiczne, Warszawa, $36 \mathrm{pp}$.

Subotowicz, W., 1982. Litodynamika brzegów klifowych wybrzeża Polski [Litodynamic of the Polish cliff coasts]. GTN - Ossolineum, Wrocław, 150 pp.

Subotowicz, W., 1989. Badania brzegu klifowego w Jastrzębiej Górze [Studies of the cliff coast in Jastrzębia Góra]. Technika i Gospodarka Morska 7 (452), 336-339.

Subotowicz, W., 1991. Ochrona brzegu klifowego na odcinku Jastrzębia Góra - Rozewie [Protection of the cliff coast between Jastrzębia Góra and Rozewie]. Inżynieria morska i geotechnika 4, 143-145.

Subotowicz, W., 1995a. Transformation of the cliff coast in Poland. [In:] E. Mojski, (Ed.): Proceedings of the $3^{\text {rd }}$ marine geological conference "The Baltic". Prace Państwowego Instytutu Geologicznego 149, 212-214.

Subotowicz, W., 1995b. Transformation of the cliff coast in Poland. Journal of Coastal Research 22, 57-62.

Subotowicz, W., 2000. Badania geodynamiczne klifów w Polsce i problem zabezpieczenia brzegu klifowego w Jastrzębiej Górze [Geodynamic Studies of cliffs in Poland and the problem of the protection of the cliff in Jastrzebia Gora]. Inżynieria Morska i Geotechnika 5, 252-257.

Suursaar, U., Jaagus, J. \& Kullas, T., 2006. Past and future changes in sea level near the Estonian coast in relation to changes in wind climate. Boreal Environmental Research 11, 123-142.

Uścinowicz, Sz., 2003. The Southern Baltic relative sea level changes, glacio-isostatic rebound and shoreline displacement. Polish Geological Institute Special Papers $10,1-79$.

Uścinowicz, Sz., Zachowicz, J., Graniczny, M. \& Dobracki, R., 2004. Geological structure of the southern Baltic coast and related hazards. Polish Geological Institute Special Papers 15, 61-68.

Uścinowicz, Sz., 2006. A relative sea-level curve for the Polish Southern Baltic Sea. Quaternary International 145/146, 86-105.

Valdmann, A., Käärd, A., Kelpsaite, L., Kurennoy, D. \& Soomere, T., 2008. Marine coastal hazards for the eastern coasts of the Baltic Sea. Baltica 21, 3-12.

Weisse, R., Bellafiore, D., Menéndez, M., Méndez, F., Nicholls, R.J., Umgiesser, G. \& Willems, P., 2014. Changing extreme sea levels along European coasts. Coastal Engineering 87, 4-14.
Wiśniewski, B. \& Wolski, T., 2009. Katalog wezbrań i obniżeń sztormowych poziomów morza oraz ekstremalne poziomy wód na polskim wybrzeżu [Catalogue of increases and decreases of the sea levels and extreme water levels on the Polish coast]. Wydawnictwo Naukowe Akademii Morskiej, Szczecin, 157 pp.

Werno, M., 2002. Zabezpieczenie zbocza klifu w Jastrzębiej Górze [Protection of the cliff slope in Jastrzebia Gora]. [In:] J. Zachowicz, R. Kramarska (Eds): Geologia regionu Gdańskiego - Przewodnik LXXIII Zjazdu PTG: [Geology of the Gdańsk region]. Polish Geological Institute, Gdańsk, 67-68.

Zachowicz, J., Uścinowicz, Sz., Jegliński, W. \& Zaleszkiewicz, L., 2007. Mapa geodynamiczna polskiej strefy brzegowej Bałtyku w skali 1:10 000, arkusze: Karwia, Jastrzębia Góra - Rozewie wraz z objaśnieniami [Geodynamic Map of the Polish coastal zone of the Baltic Sea in the scale of 1:10 000 with explanatory notes]. Polish Geological Institute - National Research Institute, Warszawa-Gdańsk.

Zaleszkiewicz, L., Masłowska, M., Olszak, I., Koszka-Maroń, D. \& Michałowska, M., 2000. Klif w Jastrzębiej Górze [Jastrzębia Góra cliff]. [In:] Uścinowicz Sz. \& Zachowicz J., (Eds): Stratygrafia czwartorzędu $i$ zanik lądolodu na Pojezierzu Kaszubskim - VII konferencja „Stratygrafia Plejstocenu Polski” [Quaternary stratigraphy and the the ice sheet retreat in the Kaszuby Lake District]. Polish Geological Institute, Gdańsk, 117-119.

Zawadzka, E., 1999. Tendencje rozwojowe polskich brzegów Battyku Potudniowego [Trends of development of the Polish Southern Baltic coastline]. Gdańskie Towarzystwo Naukowe, Gdańsk, 147 pp. (in Polish with English summary).

Zawadzka, E., 2005. Recent shore changes of Karwia sandbar. Peribalticum 9, 56-78.

Zawadzka, E., 2012. Morfodynamika brzegów wydmowych potudniowego Battyku. [Morphodynamics of the southern Baltic dune coasts]. Wydawnictwo Uniwersytetu Gdańskiego, Gdańsk, 353 pp. (in Polish with English summary).

Zeidler, R., 1995. Vulenerability of Poland's coastal areas to sea level rise. Journal of Coastal Research 22, 99-109.

Zhang, W., Harff, J., Schneider, R. \& Wu, C. 2010. Development of a modelling methodology for simulation of long-term morphological evolution of the southern Baltic coast. Ocean Dynamics 60, 1085-1114.

Zhang, W., Harff, J., Schneider, R., Meyer, M. \& Wu, C. 2011. A multiscale centennial morphodynamic model for the Southern Baltic coast. Journal of Coastal Research $27,890-917$.

Manuscript received: 30 December 2013 Revision accepted: 5 September 2014 